\title{
Model matematika SMEIUR pada penyebaran penyakit campak dengan faktor pengobatan
}

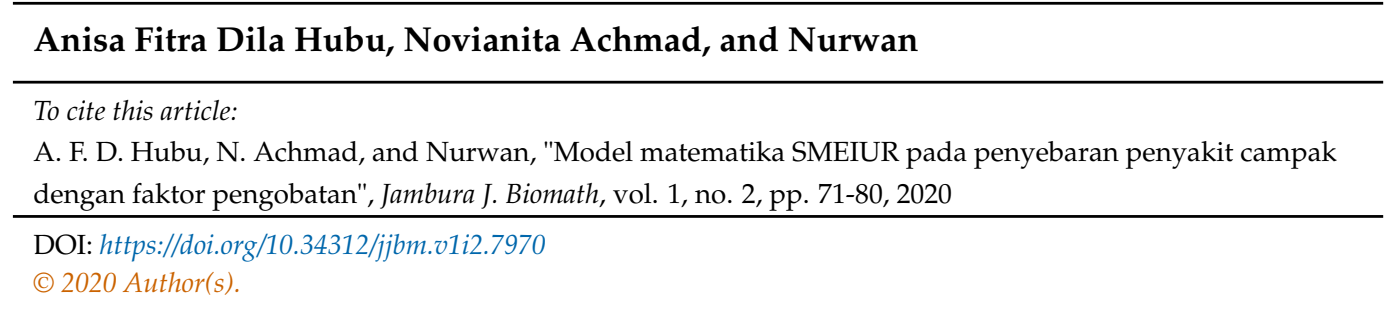

Articles You may be interested in

Global stability of a fractional-order logistic growth model with infectious disease

H. S. Panigoro and E. Rahmi

https://doi.org/10.34312/jjbm.v1i2.8135

Analisis dinamik model SVEIR pada penyebaran penyakit campak

S. O. S. P. Ahaya, E. Rahmi, and Nurwan

https://doi.org/10.34312/jjbm.v1i2.8482

Parameters estimation of generalized Richards model for COVID-19 cases in Indonesia using genetic algorithm

M. Rayungsari, M. Aufin, and N. Imamah

http://dx.doi.org/10.34312/jjbm.v1i1.6910

Analisis kestabilan model predator-prey dengan infeksi penyakit pada prey dan pemanenan proporsional pada predator

S. Maisaroh, Resmawan, and E. Rahmi

http://dx.doi.org/10.34312/jjbm.v1i1.5948

Bifurkasi Hopf pada model Lotka-Volterra orde-fraksional dengan

Efek Allee aditif pada predator

H. S. Panigoro and D. Savitri

http://dx.doi.org/10.34312/jjbm.v1i1.6908 


\title{
Model matematika SMEIUR pada penyebaran penyakit campak dengan faktor pengobatan
}

\author{
Anisa Fitra Dila Hubu ${ }^{1}$, Novianita Achmad ${ }^{1, *}$, Nurwan $^{1}$ \\ ${ }^{1}$ Jurusan Matematika, Universitas Negeri Gorontalo, Gorontalo 96128, Indonesia \\ *Penulis Korespondensi. Email: achmadnovianita@gmail.com
}

\begin{abstract}
Abstrak
Pada penelitian ini dibahas penyebaran penyakit campak yang dibuat dalam model matematika. Pemodelan matematika tidak hanya terbatas dalam dunia matematika tetapi juga dapat diaplikasikan dalam bidang kesehatan. Penyakit campak adalah penyakit dengan tingkat penularan yang tinggi. Penyebaran penyakit campak pada model ini dimodifikasi dengan menambahkan populasi terobat dan parameter pengobatan populasi terpapar. Dalam artikel ini, dilakukan pencarian titik kesetimbangan pada model matematika SMEIUR dan dilakukan analisis kestabilan. Pada penelitian ini diperoleh dua titik kesetimbangan, yaitu titik kesetimbangan bebas penyakit dan endemik. Setelah mendapatkan titik kesetimbangan, dilakukan analisis untuk mencari kestabilan model tersebut. Selanjutnya, dalam simulasi menghasilkan titik kesetimbangan bebas penyakit stabil pada kondisi $\mathrm{R}_{0}<1$ dan titik kesetimbangan endemik stabil pada kondisi $\mathrm{R}_{0}>1$. Pada penelitian ini dilakukan simulasi numerik untuk melihat dinamika populasi dengan melakukan variasi pada nilai-nilai parameter. Hasil simulasi menunjukan bahwa untuk menekan penyebaran penyakit campak, harus dilakukan peningkatan pada laju imunisasi lanjut, laju pengobatan pada individu yang terinfeksi, dan proporsi kesembuhan individu terobat.
\end{abstract}

Kata Kunci: Campak; Model Matematika SMEIUR; Titik Kesetimbangan; Bilangan Reproduksi, Analisis Kestabilan; Simulasi Numerik

\begin{abstract}
This study discusses the spread of measles in a mathematical model. Mathematical modeling is not only limited to the world of mathematics but can also be applied in the health sector. Measles is a disease with a high transmission rate. The spread of measles in this model was modified by adding the treated population and the treatment parameters of the exposed population. In this article, we examine the equilibrium points in the SMEIUR mathematical model and perform stability analysis and numerical simulations. In this study, two equilibrium points were obtained, namely the disease-free and endemic equilibrium point. After getting the equilibrium point, an analysis is carried out to find the stability of the model. Furthermore, the simulation produces a stable disease-free equilibrium point at conditions $R_{0}<1$ and a stable endemic equilibrium point at conditions $R_{0}>1$. In this study, a numerical simulation was carried out to see population dynamics by varying the parameter values. The simulation results show that to reduce the spread of measles, it is necessary to increase the rate of advanced immunization, the rate of the infected population undergoing treatment, and the proportion of individuals who are treated cured.
\end{abstract}

Keywords: Measles; SMEIUR Mathematical Model; Equilibrium Point; Reproduction Numbers; Stability Analysis; Numerical Simulation

\section{Pendahuluan}

Pemodelan matematika merupakan salah satu konsep yang dapat digunakan untuk mempresentasikan suatu kejadian dengan menyederhanakan dalam bentuk asumsi-asumsi yang mudah untuk dipahami [1]. Penyakit campak adalah penyakit menular yang dapat dianalisis melalui pemodelan matematika. Virus campak merupakan salah satu mikroorganisme yang sangat mudah menular antara individu satu ke individu yang lain, terutama pada anak-anak yang memasuki usia pra-sekolah dan tamat SD [2]. Suspek campak pada tahun 2018 tersebar hampir di seluruh wilayah Indonesia, dengan Incidence Rate (IR) sebesar 3,18 per 100.000 penduduk [3].

Penyebaran penyakit campak telah banyak diteliti dalam perspektif pemodelan matematika. Fred dkk [4] memperkenalkan dan menganalisis model dinamika penularan virus campak yang terjadi di KISII Kenya pada tahun 2011 sampai 2013. Momoh dkk [5] menganalisis model dinamika penularan virus campak dengan pemeriksaan dan terapi pada populasi manusia terekspos untuk mengontrol penyebaran penyakit. Edward dkk [6] melakukan analisis terhadap campak dengan faktor vaksinasi. Model yang digunakan adalah model SVEIR. Dalam model ini terdapat 5 populasi, yaitu $S$ populasi manusia rentan (susceptible), $V$ populasi tervaksin (vaccinated), E populasi manusia terekspos (exposed), I populasi manusia terinfeksi (infected), dan $R$ yang menyatakan populasi manusia yang pulih pasca terinfeksi penyakit atau kebal terhadap penyakit (recovered). Adapun Garba dkk [7] telah melakukan penelitian dengan melakukan analisis terhadap model matematika pada dinamika virus campak dengan membagi populasi menjadi dua yaitu populasi tervaksin dan tidak 


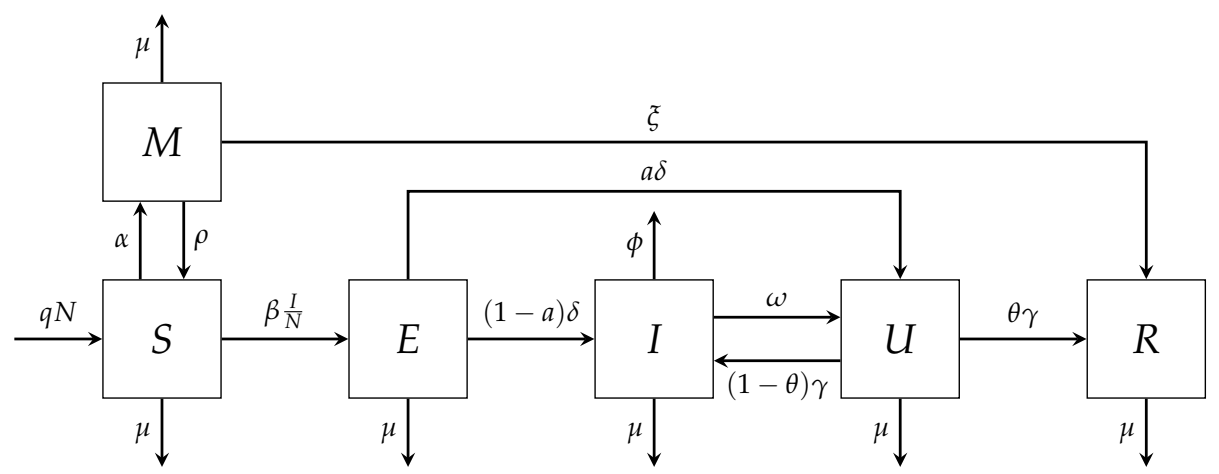

Gambar 1. Diagram kompratemen penyakit campak dengan faktor pengobatan

tervaksin. Selanjutnya, model penyebaran penyakit yang disebabkan oleh virus campak dengan membagi populasi manusia terinfeksi menjadi dua tahapan, yaitu populasi manusia terinfeksi tahap pertama (catarrh infected) dan populasi manusia terinfeksi tahap kedua (eruption infected) yang diperkenalkan oleh Mitku dan Koya [8]. Selanjutnya, model dari dua penelitian tersebut dikembangkan oleh Zanuarini [9] dengan menggabungkan kedua model dan menambahkan 2 populasi, yaitu populasi terobat dan populasi gagal terobat sehingga pada penelitiannya terbagi menjadi 8 populasi.

Campak termasuk salah satu penyakit yang membutuhkan imunisasi lanjutan. Selain imunisasi, diberikan pengobatan pada penderita penyakit campak. Obat-obat yang diberikan bukan untuk mengobati penyakit campak tersebut, melainkan berfungsi untuk menurunkan risiko dari gejala-gejala yang ditimbulkan dari penyakit campak tersebut [10]. Berdasarkan hal tersebut, dalam penelitian ini dimodifikasi model yang diajukan oleh Edward dkk. [6] dengan menambahkan populasi yang melakukan pengobatan $(U)$ maupun parameter yang menyatakan pengobatan baik pada populasi terpapar dan terinfeksi. Hal ini dilakukan untuk mempelajari dinamika model penyebaran campak dengan adanya populasi yang melakukan pengobatan baik yang berasal dari populasi terpapar maupun terinfeksi terhadap penyebaran campak.

\section{Formulasi Model}

Model matematika dikarakterisasi dengan asumsi tentang variable, parameter dan bentuk fungsi [11]. Model matematika pada penelitian ini adalah hasil modifikasi dari model matematika penyebaran penyakit campak oleh Edward dkk [6]. Pada penelitian ini populasi vaksin $(V)$ yang ada pada model sebelumnya diubah menjadi populasi imunisasi $(M)$ karena berdasarkan referensi bahwa penanganan campak dilakukan dengan memberikan imunisasi dasar dan imunisasi lanjut. Penelitian ini juga menambahkan populasi $U$ yaitu populasi yang melakukan pengobatan. Penambahan populasi pengobatan dilakukan seperti pada model yang diajukan oleh Zainuri dkk [9] dengan alasan bahwa gejala campak bisa dicegah maupun diatasi dengan pengobatan. Dalam penelitian ini juga menambahkan parameter populasi terpapar melakukan pengobatan, karena pengobatan campak juga bisa menurunkan resiko dari gejala-gejala campak sehingga populasi terpapar yang melakukan pencegahan akan menurun resiko bahkan akan tercegah dari kelas infeksi yang sudah memiliki tingkat gejala yang lebih parah. Sehingga, pada model ini terdapat 6 populasi, yaitu $S$ populasi rentan (Susceptible), M populasi yang di imunisasi (Immune), E populasi yang terpapar (Exposed), I populasi yang sudah terinfeksi (Infected), $U$ populasi yang melakukan pengobatan (Treatment), dan $R$ populasi yang sudah sembuh (Recovered). Beberapa asumsi yang digunakan pada penelitian ini adalah sebagai berikut.

1. Individu masuk ke populasi $S$ adalah faktor kelahiran.

2. Tingkat kelahiran per kapita konstan.

3. Tingkat kematian alami per kapita konstan.

4. Populasi rentan yang melakukan imunisasi dasar akan berpindah menjadi populasi terimunisasi.

5. Populasi terimunisasi yang melakukan imunisasi lanjut akan sembuh.

6. Populasi terimunisasi yang tidak melakukan imunisasi lanjut akan kembali rentan.

7. Individu terpapar diberikan pengobatan dan berpindah ke populasi yang melakukan pengobatan.

8. individu dapat terinfeksi melalui kontak langsung dengan individu yang terinfeksi.

9. Populasi yang telah sembuh akan kebal terhadap virus campak dan tidak akan kembali rentan.

10. Penyakit dapat menyebabkan kematian.

11. Tidak terjadi migrasi pada setiap populasi 
Dari asumsi-asumsi di atas yang diilustrasikan oleh diagram kompartemen pada Gambar 1, diperoleh sistem persamaan diferensial berikut.

$$
\begin{aligned}
\frac{d S}{d t} & =q N-\alpha S-\beta \frac{I}{N} S+\rho M-\mu S \\
\frac{d M}{d t} & =\alpha S-\xi S-\rho M-\mu M \\
\frac{d E}{d t} & =\beta \frac{I}{N} S-a \delta E-(1-a) \delta E-\mu E \\
\frac{d I}{d t} & =(1-a) \delta E+(1-\theta) \gamma U-\omega I-\phi I-\mu I \\
\frac{d U}{d t} & =\alpha \delta E+\omega I-(1-\theta) \gamma U-\theta \gamma U-\mu U \\
\frac{d R}{d t} & =\xi M+\theta \gamma U-\mu R
\end{aligned}
$$

Total populasi dapat ditulis $N=S+M+E+I+U+R$. Untuk selanjutnya dilakukan penskalaan terhadap variabel yang bertujuan untuk memudahkan proses analisis model. Dengan mendefinisikan variabel-variabel baru sebagai berikut : $s=\frac{S}{N}, m=\frac{M}{N}, e=\frac{E}{N}, i=\frac{I}{N}, u=\frac{U}{N}$, dan $r=\frac{R}{N}$, diperoleh

$$
\begin{aligned}
\frac{d s}{d t} & =q-\alpha s-\beta i s+\rho m-\mu s \\
\frac{d m}{d t} & =\alpha s-\xi s-\rho m-\mu m \\
\frac{d e}{d t} & =\beta i s-a \delta e-(1-a) \delta e-\mu e \\
\frac{d i}{d t} & =(1-a) \delta e+(1-\theta) \gamma u-\omega i-\phi i-\mu i \\
\frac{d u}{d t} & =\alpha \delta e+\omega i-(1-\theta) \gamma u-\theta \gamma u-\mu u \\
\frac{d r}{d t} & =\xi m+\theta \gamma u-\mu r
\end{aligned}
$$

\section{Titik Kesetimbangan}

Titik kesetimbangan merupakan solusi sistem persamaan diferensial yang tidak berubah terhadap waktu [12]. Titik kesetimbangan disebut juga titik kritis atau titik ekuilibrium dari suatu sistem dinamik [13].

Titik kesetimbangan pada penyakit campak dapat diklasifikasikan menjadi dua, yaitu titik kesetimbangan bebas penyakit dan titik kesetimbangan endemik. Berdasarkan sistem (2): $\frac{d s}{d t}=\frac{d m}{d t}=\frac{d e}{d t}=\frac{d i}{d t}=\frac{d u}{d t}=\frac{d r}{d t}=0$, diperoleh dua titik kesetimbangan, yaitu:

1. Titik kesetimbangan bebas penyakit

$$
E_{0}^{*}=\left(s_{0}, m_{0}, e_{0}, i_{0}, u_{0}, r_{0}\right)
$$

dengan $s_{0}=\frac{q(\xi+\rho+\mu)}{(\alpha+\mu)(\xi+\mu)+\mu \rho}, m_{0}=\frac{\alpha q}{(\alpha+\mu)(\xi+\mu)+\mu \rho}, e_{0}=i_{0}=u_{0}=0$, dan $r_{0}=\frac{\xi \alpha q}{\mu((\alpha+\mu)(\xi+\mu)+\mu \rho)}$.

2. Titik kesetimbangan endemik

$$
E_{1}^{*}=\left(s_{1}, m_{1}, e_{1}, i_{1}, u_{1}, r_{1}\right)
$$

dengan

$$
\begin{aligned}
& s_{1}=-\frac{(\delta+\mu)(\mu(\mu+\phi+\omega)+\gamma(\mu+\phi+\theta \omega))}{\beta \delta(\gamma(-1+a \theta)+(-1+a) \mu)}, \quad m_{1}=-\frac{\alpha(\delta+\mu)(\mu(\mu+\phi+\omega)+\gamma(\mu+\phi+\theta \omega)}{\beta \delta(\gamma(-1+a \theta)+(-1+a) \mu)(\mu+\xi+\rho)}, \\
& e_{1}=\frac{q}{\delta+\mu}, \quad i_{1}=-\frac{(\alpha+\mu)(\mu+\xi)+\mu \rho}{\beta(\mu+\xi+\rho)}+\frac{q \delta(\gamma-a \gamma \theta+\mu-a \mu)}{(\delta+\mu)(\mu(\mu+\phi+\omega)+\gamma(\mu+\phi+\theta \omega))}, \\
& u_{1}=\frac{((a(\mu+\phi)+\omega)(q \beta \delta(\gamma(-1+a \theta)+(-1+a) \mu)(\mu+\xi+\rho)+(\delta+\mu)((\alpha+\mu)(\mu+\xi)+\mu \rho)(\mu(\mu+\phi+\omega)+\gamma(\mu+\phi+\theta \omega)))}{(\beta(\delta+\mu)(\gamma(-1+a \theta)+(-1+\alpha) \mu)(\mu+\xi+\rho)}, \\
& r_{1}=\left(b_{1}+b_{2}+b_{3}\right),
\end{aligned}
$$


dan

$$
\begin{aligned}
& b_{1}=\frac{a^{2} q \beta \gamma \delta^{2} \theta(\gamma \theta+\mu)(\mu+\xi+\rho)(\mu+\phi)-\alpha(\delta+\mu((\gamma+\mu)(\delta+\mu) \xi(\mu+\phi)+\mu((\delta+\mu) \xi+\gamma \theta(-\delta+\xi)) \omega)(\mu(\mu+\phi+\omega)+\gamma(\mu+\phi+\theta \omega))}{(\beta \delta \mu(\delta+\mu)(\gamma(-1+a \theta)+(-1+a) \mu)(\mu+\xi+\rho)(\mu(\mu+\phi+\omega)+\gamma(\mu+\phi+\theta \omega)))}, \\
& b_{2}=\frac{\gamma \delta \theta(\mu+\xi+\rho) \omega(-q \beta \delta(\gamma+\mu)+\mu(\delta+\mu)((\gamma+\mu)(\mu+\varphi)+(\gamma \theta+\mu) \omega))}{(\beta \delta \mu(\delta+\mu)(\gamma(-1+a \theta)+(-1+a) \mu)(\mu+\xi+\rho)(\mu(\mu+\varphi+\omega)+\gamma(\mu+\varphi+\theta \omega)))} \\
& b_{3}=\frac{a \gamma \delta \theta(q \beta \delta(\mu+\xi+\rho)(-(\gamma+\mu)(\mu+\varphi)+(\gamma \theta+\mu) \omega)+(\delta+\mu)((\alpha+\mu)(\mu+\xi)+\mu \rho)(\mu+\varphi)((\gamma+\mu)(\mu+\varphi)+(\gamma \theta+\mu) \omega))}{(\beta \delta \mu(\delta+\mu)(\gamma(-1+a \theta)+(-1+a) \mu)(\mu+\xi+\rho)(\mu(\mu+\varphi+\omega)+\gamma(\mu+\varphi+\theta \omega)))} .
\end{aligned}
$$

\section{Bilangan Reproduksi Dasar}

Hethcote [14] menyatakan bahwa bilangan reproduksi dasar merupakan rasio yang menunjukkan jumlah individu rentan yang dapat menderita penyakit yang disebabkan oleh satu individu infeksi. Untuk menghitung bilangan reproduksi dasar $\left(R_{0}\right)$, dibentuk matriks $\phi$ dan $\psi$. Matrik $\phi$ menyatakan laju infeksi yang mengakibatkan bertambahnya kelas infeksi, dan matriks $\psi$ menyatakan laju infeksi yang mengakibatkan berkurangnya kelas infeksi, sehingga berdasarkan sistem (2) diperoleh :

$$
\begin{gathered}
\varphi=\left[\begin{array}{c}
\beta s i \\
0 \\
0
\end{array}\right] \\
\psi=\left[\begin{array}{c}
a \delta e+(1-a) \delta e+\mu e \\
-(1-a) \delta e-(1-\theta) \gamma u+\omega i+\phi i+\mu i \\
-a \delta e-\omega i+(1-\theta) \gamma u+\theta \gamma u+\mu u
\end{array}\right]
\end{gathered}
$$

Selanjutnya $F$ adalah matriks Jacobi dari $\varphi$ yang dihitung di titik bebas penyakit dan $V$ adalah matriks Jacobi dari $\psi$, sehingga diperoleh

$$
\begin{gathered}
F=\left[\begin{array}{ccc}
0 & \frac{\beta q(\xi+\rho+\mu)}{(\alpha+\mu)(\xi+\mu)+\mu \rho} & 0 \\
0 & 0 & 0 \\
0 & 0 & 0
\end{array}\right] \\
V=\left[\begin{array}{ccc}
a \delta+(1-a) \delta+\mu & 0 & 0 \\
-(1-a) \delta & \omega+\phi+\mu & -(1-\theta) \gamma \\
-a \delta & -\omega & (1-\theta) \gamma+\theta \gamma+\mu
\end{array}\right]
\end{gathered}
$$

Bilangan reproduksi dasar diperoleh dari nilai eigen terbesar dari $\left[F V^{-1}\right][15]$, sehingga diperoleh

$$
R_{0}=\frac{q \beta \delta(\gamma(1-\theta)+(1-a)(\theta \gamma+\mu))(\mu+\xi+\rho)}{((\delta+\mu)((\alpha+\mu)(\mu+\xi)+\mu \rho)(\gamma(1-\theta)(\mu+\phi)(\theta \gamma+\mu)(\mu+\phi+\omega)))}
$$

\section{Analisis Kestabilan}

Analisis kestabilan dilakukan untuk setiap nilai eigen yang diperoleh [13]. Untuk menyelidiki kestabilan lokal titik kesetimbangan model, dilakukan dengan cara mensubstitusikan titik-titik kesetimbangan kedalam sistem yang telah dilinearkan. Untuk mencari kestabilan kesetimbangan bebas penyakit, subtitusi $E_{0}^{*}$ ke matriks Jacobi sehingga menghasilkan matriks Jacobi sebagai berikut.

$$
J\left(E_{0}^{*}\right)=\left[\begin{array}{cccccc}
A_{11} & A_{12} & 0 & A_{14} & 0 & 0 \\
A_{21} & A_{22} & 0 & 0 & 0 & 0 \\
0 & 0 & A_{33} & A_{34} & 0 & 0 \\
0 & 0 & A_{43} & A_{44} & A_{45} & 0 \\
0 & 0 & A_{53} & A_{54} & A_{55} & 0 \\
0 & A_{62} & 0 & 0 & A_{65} & A_{66}
\end{array}\right]
$$

dengan

$$
\begin{array}{lll}
A_{11}=-(\alpha+\mu)<0, & A_{12}=\rho>0, & A_{14}=-\frac{q \beta(\xi+\rho+\mu)}{(\alpha+\mu)(\xi+\mu)+\mu \rho}<0, \\
A_{21}=\alpha>0, & A_{22}=-\xi-\rho-\mu<0, & A_{33}=-a \delta-(1-a) \delta-\mu<0, \\
A_{34}=\frac{q \beta(\xi+\rho+\mu)}{(\alpha+\mu)(\xi+\mu)+\mu \rho}>0, & A_{43}=(1-a) \delta>0, & A_{44}=-\omega-\phi-\mu<0, \\
A_{45}=(1-\theta) \gamma>0, & A_{53}=a \delta>0, & A_{54}=\omega>0, \\
A_{55}=-(1-\theta) \gamma-\theta \gamma-\mu<0, & A_{62}=\xi>0, & A_{65}=\theta \gamma>0, A_{66}=-\mu<0 .
\end{array}
$$


Selanjutnya mencari persamaan karakteristik dari persamaan (8) dengan mencari $\operatorname{det}\left(\lambda I-J\left(E_{0}^{*}\right)\right)=0$, sehingga diperoleh

$$
\begin{aligned}
\left(A_{66}-\lambda\right)\left(A_{12} A_{21}\right. & \left.+\left(A_{11}-\lambda\right)\left(-A_{22}+\lambda\right)\right) \\
( & \left(-A_{34}\left(A_{45} A_{53}+A_{43}\left(-A_{55}+\lambda\right)\right)+\left(A_{33}-\lambda\right)\left(A_{45} A_{54}+\left(A_{44}-\lambda\right)\left(-A_{55}+\lambda\right)\right)\right)=0 .
\end{aligned}
$$

Berdasarkan persamaan (9) diperoleh 6 nilai eigen. Nilai eigen pertama diperoleh $\lambda_{1}=A_{66}=-\mu$. Karena semua nilai parameter positif, maka $\lambda_{1}<0$. Untuk kelima nilai eigen lainnya diperoleh dengan menyelesaikan persamaan berikut.

$$
\begin{array}{r}
\lambda^{2}+\left(-A_{11}-A_{22}\right) \lambda+\left(A_{11} A_{22}-A_{12} A_{21}\right)=0 \\
\lambda^{3}+\left(-A_{33}-A_{44}-A_{55}\right) \lambda^{2}+\left(-A_{34} A_{43}+A_{33} A_{44}-A_{45} A_{54}+A_{33} A_{55}+A_{44} A_{55}\right) \lambda+ \\
\left(-A_{34} A_{45} A_{54}+A_{44} A_{45} A_{54}+A_{34} A_{43} A_{55}-A_{33} A_{44} A_{55}\right)=0 .
\end{array}
$$

Teorema 1. Titik kesetimbangan bebas penyakit $E_{0}^{*}$ untuk sistem (2) bersifat stabil asimtotik lokal jika:

$$
\begin{aligned}
\alpha+2 \mu+\xi+\rho & >0, \\
(\alpha+\mu)(\mu+\xi+\rho)-\alpha & >0, \\
\lambda_{4}+\lambda_{5}+\lambda_{6} & =-a_{1}, \\
\lambda_{4} \lambda_{5}+\lambda_{4} \lambda_{6}+\lambda_{5} \lambda_{6} & =a_{2} \\
\lambda_{4}+\lambda_{5}+\lambda_{6} & =-a_{3}
\end{aligned}
$$

bukti. Persamaan (10) dapat ditulis kembali dalam bentuk

$$
a_{0} \lambda^{2}+a_{1} \lambda+a_{2}=0
$$

dengan

$$
a_{0}=1, a_{1}=-A_{11}-A_{22}, a_{2}=(\alpha+\mu)(\mu+\xi+\rho)-\alpha .
$$

Untuk memastikan apakah semua akar pada persamaan (12) memiliki bagian real negatif, maka akan ditunjukan $a_{1}>0$ dan $a_{2}>0$.

(i.) Menunjukkan $a_{1}>0$.

Karena $A_{11}<0$ dan $A_{22}<0$ maka $a_{1}=-A_{11}-A_{22}>0$.

(ii.) Menunjukkan $a_{2}>0$.

Karena semua parameter bernilai positif maka $a_{2}>0$ jika $(\alpha+\mu)(\mu+\xi+\rho)-\alpha>0$.

Karena $a_{1}>0$ dan $a_{2}>0$, maka terbukti kedua nilai eigen bernilai negative $\left(\lambda_{2}<0, \lambda_{3}<0\right)$. Selanjutnya, persamaan (11) dapat ditulis kembali dalam bentuk

$$
a_{0} \lambda^{3}+a_{1} \lambda^{2}+a_{2} \lambda+a_{3}=0
$$

dengan $a_{0}=1, a_{1}=-A_{33}-A_{44}-A_{55}, a_{2}=c_{1}-c_{2}, a_{3}=c_{3}-c_{4}$, dan

$$
\begin{aligned}
& c_{1}=\left(\delta(2 \mu+\phi+\omega)+\gamma(\delta+2 \mu+\phi+\theta \omega)+\mu(3 \mu+2(\phi+\omega))+\frac{a q \beta \delta(\mu+\xi+\rho)}{(\alpha+\mu)(\mu+\xi)+\mu \rho}\right), \\
& c_{2}=\frac{q \beta \delta(\mu+\xi+\rho)}{(\alpha+\mu)(\mu+\xi)+\mu \rho}, \\
& c_{3}=\left(\mu(\delta+\mu)(\mu+\phi+\omega)+\gamma(\delta+\mu)(\mu+\phi+\theta \omega)+\frac{a q \beta \delta(\gamma \theta+\mu)(\mu+\xi+\rho)}{(\alpha+\mu)(\mu+\xi)+\mu \rho}\right) .
\end{aligned}
$$

Akar-akar persamaan (13) merupakan nilai eigen lain dari persamaan karakteristik (9) yaitu $\lambda_{4}, \lambda_{5}$ dan $\lambda_{6}$. Berdasarkan sifat akar persamaan kubik, diperoleh persamaan berikut.

$$
\begin{aligned}
\lambda_{4}+\lambda_{5}+\lambda_{6} & =-a_{1} \\
\lambda_{4} \lambda_{5}+\lambda_{4} \lambda_{6}+\lambda_{5} \lambda_{6} & =a_{2} \\
\lambda_{4}+\lambda_{5}+\lambda_{6} & =-a_{3}
\end{aligned}
$$


Tabel 1. Nilai parameter untuk kondisi $R_{0}<1$ dan $R_{0}>1$

\begin{tabular}{cccc}
\hline Parameter & $R_{0}<1$ & $R_{0}>1$ & Sumber \\
\hline$q$ & 0,6 & 0,6 & Asumsi \\
$\alpha$ & 0,5 & 0,4 & Asumsi \\
$\xi$ & 0,4 & 0,2 & Asumsi \\
$\rho$ & 0,2 & 0,5 & Asumsi \\
$\beta$ & 0,2 & 0,4 & Asumsi \\
$\delta$ & 0,7 & 0,6 & Asumsi \\
$\omega$ & 0,012 & 0,012 & {$[7]$} \\
$\theta$ & 0,7 & 0,6 & Asumsi \\
$\phi$ & 0,125 & 0,125 & {$[6]$} \\
$\gamma$ & 0,143 & 0,143 & {$[7]$} \\
$a$ & 0,5 & 0,1 & Asumsi \\
$\mu$ & 0,25 & 0,15 & Asumsi \\
\hline
\end{tabular}

(i) Tinjau $a_{1}$.

Karena $A_{33}<0, A_{44}<0$, dan $A_{55}<0$, maka $a_{1}=-\left(A_{33}+A_{44}-A_{55}\right)>0$, sehingga diperoleh

$$
\lambda_{4}+\lambda_{5}+\lambda_{6}<0
$$

Berdasarkan persamaan (15), dapat diketahui bahwa jumlah ketiga nilai eigen bernilai negatif. Hal ini menandakan bahwa paling sedikit satu nilai eigen bernilai negatif.

Asumsikan $\lambda_{4}<0$.

(ii) Tinjau $a_{2}$. Jelas bahwa $a_{2}>0$ jika $c_{1}>c_{2}$.

(iii) Tinjau $a_{3}$. Jelas bahwa $a_{3}>0$ jika $c_{3}>c_{4}$.

Karena $a_{2}>0$ dan $a_{3}>0$, maka kedua nilai tersebut memenuhi kondisi berikut

$$
\begin{aligned}
\lambda_{4}\left(\lambda_{5}+\lambda_{6}\right)+\lambda_{5} \lambda_{6} & >0 \\
\lambda_{4} \lambda_{5} \lambda_{6} & <0
\end{aligned}
$$

Karena $\lambda_{4}<0$ dan persamaan (17) terpenuhi, maka

$$
\lambda_{5} \lambda_{6}>0
$$

berdasarkan persamaan (16) dan (18), maka

$$
\lambda_{5}+\lambda_{6}<0
$$

Persamaan (18) dan (19) dapat terpenuhi jika dan hanya jika $\lambda_{5}<0$ dan $\lambda_{6}<0$. Hal ini menandakan bahwa semua nilai eigen bernilai negatif $\left(\lambda_{4}<0, \lambda_{5}<0\right.$ dan $\left.\lambda_{6}<0\right)$. Dengan demikian semua nilai eigen dari persamaan karakteristik (12) dan (13) negatif, $\lambda_{1}<0, \lambda_{2}<0, \lambda_{3}<0, \lambda_{4}<0, \lambda_{5}<0$ dan $\lambda_{6}<0$. Jadi, terbukti bahwa titik kesetimbangan bebas campak stabil asimtotik.

\section{Simulasi}

Simulasi pada model hasil modifikasi dilakukan dengan menggunakan software Python 3.7 untuk menunjukkan sifat kestabilan dari masing-masing titik kesetimbangan dengan memasukkan nilai-nilai parameter pada Tabel 1. Kemudian, simulasi dilakukan untuk mempelajari dinamika populasi manusia yang terjadi dalam sistem dinamik dengan melakukan variasi nilai-nilai parameter, yaitu laju populasi terimunisasi yang melakukan imunisasi lanjut $(\xi)$, laju pengobatan pada populasi yang terinfeksi $(\omega)$, dan proporsi kesembuhan individu terobat $(\theta)$.

\subsection{Dinamika populasi untuk kondisi $R_{0}<1$}

Dinamika populasi pada kondisi $R_{0}<1$ ditunjukan pada Gambar 2 dengan nilai $R_{0}=0,20$ dan nilai awal $S=2500, M=1000, E=1000, I=250, U=250, R=0$ dengan $N=5000$. Dinamika populasi manusia pada Gambar (2) menunjukkan bahwa masing-masing populasi menuju titik kesetimbangan bebas penyakit atau stabil di sekitar titik kesetimbangan bebas penyakit. Populasi rentan mengalami kenaikan dari nilai awal hingga mencapai kondisi stabil sekitar titik s =0,95 atau sekitar 4750 orang. Populasi imunisasi mengalami kenaikan dari nilai awal hingga mencapai kondisi stabil sekitar titik $m=0,56$ atau sekitar 2800 orang. Populasi terpapar 

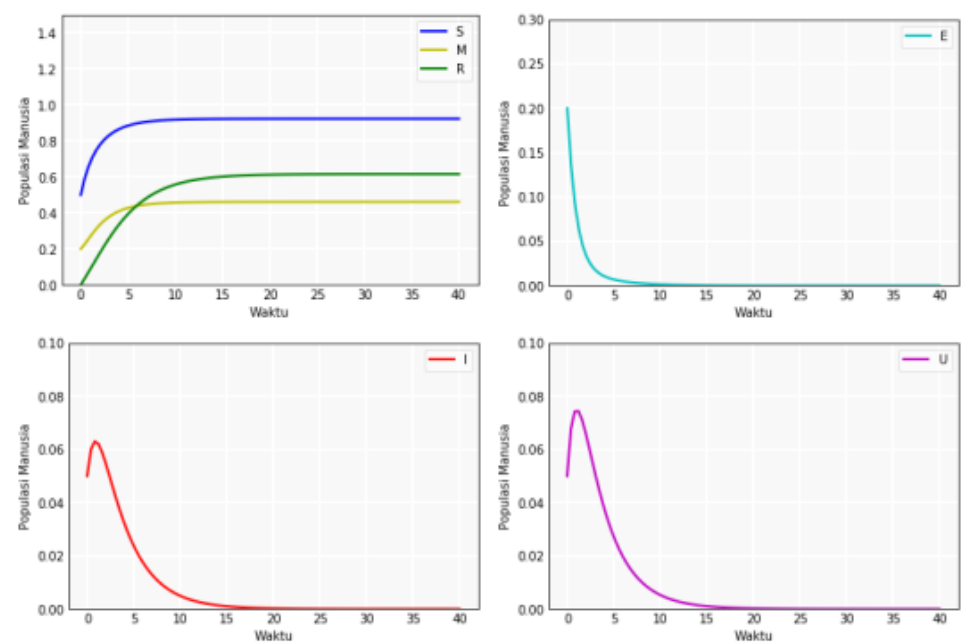

Gambar 2. Dinamika populasi $R_{0}<1$
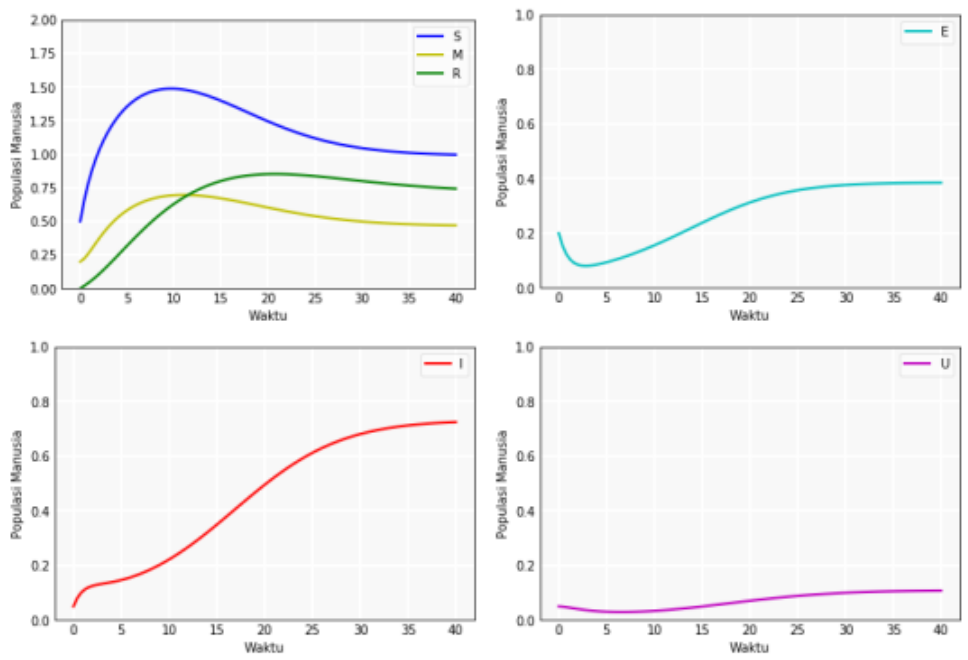

Gambar 3. Dinamika populasi $R_{0}>1$

mengalami penurunan dari nilai awal hingga mencapai kondisi stabil sekitar titik $\mathrm{e}=0$. Berikutnya, populasi terinfeksi dan populasi yang melakukan pengobatan mengalami kenaikan dari nilai awal kemudian menurun hingga mencapai kondisi stabil sekitar titik $\mathrm{i}=\mathrm{u}=0$. Adapun populasi sembuh mengalami kenaikan dari nilai awal hingga mencapai kondisi stabil sekitar titik $r=0,89$ atau sekitar 4450 orang. Hal ini membuktikan bahwa kondisi bebas penyakit campak sesuai dengan Teorema 1.

\subsection{Dinamika populasi untuk kondisi $R_{0}>1$}

Dinamika populasi pada kondisi $R_{0}>1$ ditunjukan pada Gambar 3 dengan nilai $R_{0}=1,97$ dan nilai awal $\mathrm{S}=$ $2500, \mathrm{M}=1000, \mathrm{E}=1000, \mathrm{I}=250, \mathrm{U}=250, \mathrm{R}=0$ dengan $\mathrm{N}=5000$. Dinamika populasi manusia pada Gambar 3 menunjukan bahwa masing-masing populasi menuju titik kesetimbangan endemik atau stabil disekitar titik kesetimbangan endemik. Populasi rentan mengalami kenaikan dari nilai awal kemudian menurun hingga mencapai titik stabil di sekitar $\mathrm{s}=0,99$ atau sekitar 4950. Populasi imunisasi mengalami kenaikan kemudian turun hingga mencapai titik stabildi sekitar $\mathrm{m}=0,46$ atau sekitar 2300 orang. Populasi terpapar mengalami penurunan dari nilai awal kemudian naik hingga mencapai titik stabil di sekitar e $=0,38$ atau sekitar 1900 orang. Kemudian populasi terinfeksi mengalami kenaikan dari nilai awal lalu turun kemudian naik hingga mencapai titik stabil di sekitar $\mathrm{i}=0,73$ atau sekitar 3650 orang. Adapun populasi yang melakukan pengobatan mengalami penurunan dari nilai awal lalu naik hingga mencapai titik stabil di sekitar $\mathrm{u}=0,11$ atau sekitar 550 orang . Selanjutnya populasi sembuh mengalami kenaikan dari nilai awal kemudian menurun hingga mencapai titik stabil di sekitar $\mathrm{r}=0,71$ atau sekitar 3550 orang. 
Tabel 2. Hasil variasi parameter $\xi$

\begin{tabular}{ccc}
\hline Simulasi & $\xi$ & $R_{0}$ \\
\hline 1 & 0,3 & 0,14 \\
2 & 0,5 & 0,13 \\
3 & 0,7 & 0,128 \\
4 & 0,9 & 0,126 \\
\hline
\end{tabular}
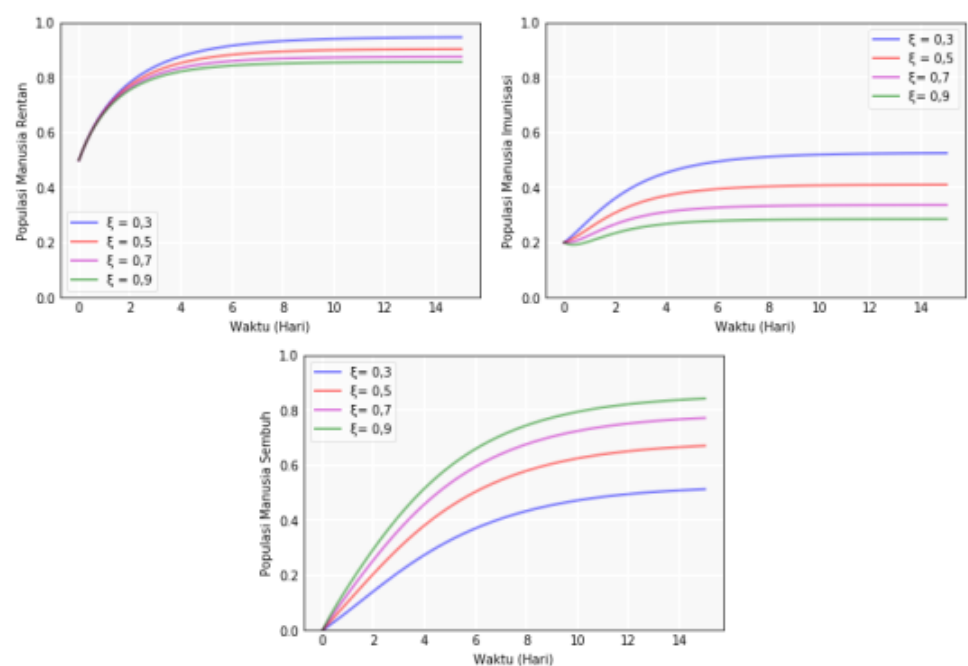

Gambar 4. Simulasi laju individu terimunisasi menjalani imunisasi lanjut

Tabel 3. Hasil variasi parameter $\omega$

\begin{tabular}{ccc}
\hline Simulasi & $\omega$ & $R_{0}$ \\
\hline 1 & 0,2 & 0,09 \\
2 & 0,4 & 0,07 \\
3 & 0,6 & 0,06 \\
4 & 0,8 & 0,05 \\
\hline
\end{tabular}

\subsection{Simulasi laju imunisasi lanjut ( $\xi)$}

Pada bagian ini dilakukan simulasi menggunakan nilai-nilai parameter pada Tabel 1 dengan beberapa variasi nilai parameter $\xi$. Simulasi ini bertujuan untuk melihat pengaruh parameter $\xi$ terhadap nilai $R_{0}$ dan pengaruhnya pada dinamika populasi penyebaran pengguna narkoba. Adapapun nilai-nilai parameter $\xi$ yang divariasikan dapat dilihat pada Tabel 2.

Pada Tabel 2 dapat dilihat bahwa semakin besar nilai parameter $\xi$ maka mengakibatkan semakin kecil nilai $R_{0}$. Maka, Upaya yang dapat dilakukan untuk menekan penyebaran penyakit campak yaitu dengan meningkatkan laju imunisasi lanjut pada individu yang sudah menjalankan imunisasi dasar. Dari Gambar 4 dapat dilihat bahwa meningkatnya parameter $\xi$ dan parameter lain tetap, dapat menyebabkan turunnya populasi imunisasi yang bisa kembali rentan sehingga populasi rentan ikut menurun. Sedangkan meningkatnnya parameter tersebut mengakibatkan populasi sembuh meningkat. Hal ini menunjukkan bahwa imunisasi lanjut cukup berperan dalam menekan penyebaran penyakit campak.

\subsection{Simulasi laju pengobatan pada individu yang terinfeksi ( $\omega)$}

Dari Gambar 5 dapat dilihat bahwa meningkatnya parameter $\omega$ dan parameter lain tetap, dapat mempengaruhi populasi infeksi, populasi yang melakukan pengobatan, dan populasi sembuh. Semakin besar laju individu yang menjalankan pengobatan, maka semakin menurun populasi terinfeksi. Sedangkan, semakin besar laju individu yang menjalankan pengobatan maka semakin meningkat populasi yang melakukan pengobatan. Untuk populasi sembuh pengaruhnya terlihat sangat kecil. Hal ini menunjukkan bahwa laju pengobatan cukup berperan dalam menekan penyebaran penyakit campak. 


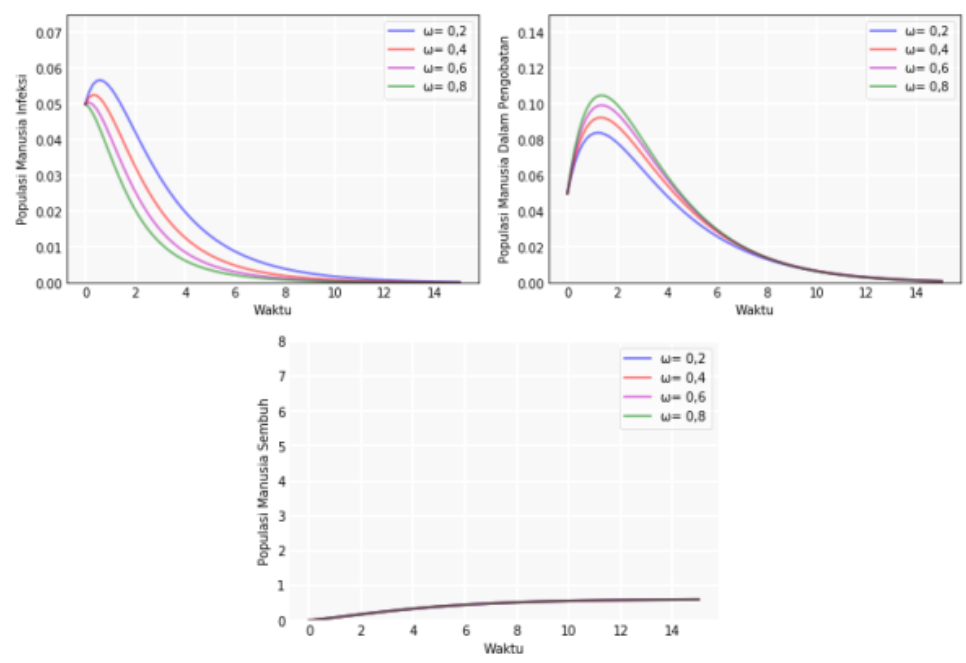

Gambar 5. Simulasi laju individu terinfeksi melakukan pengobatan

Tabel 4. Hasil variasi parameter $\theta$

\begin{tabular}{ccc}
\hline Simulasi & $\theta$ & $R_{0}$ \\
\hline 1 & 0,2 & 0,16 \\
2 & 0,4 & 0,15 \\
3 & 0,6 & 0,14 \\
4 & 0,8 & 0,13 \\
\hline
\end{tabular}
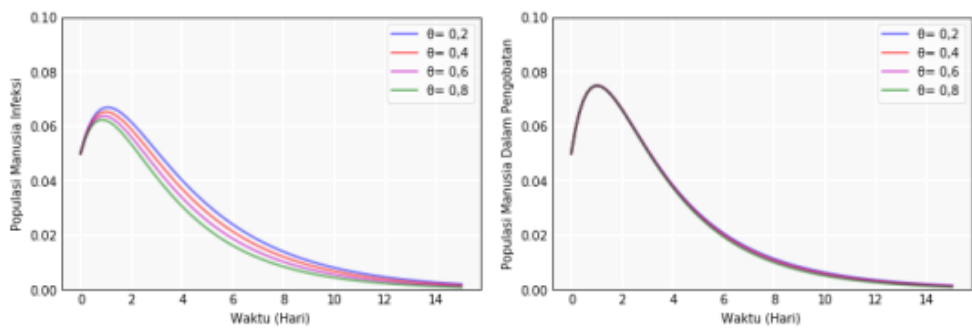

Gambar 6. Simulasi proporsi individu terobat sembuh

\subsection{Simulasi proporsi kesembuhan individu terobat $(\theta)$}

Pada Tabel 4 dapat dilihat bahwa semakin besar nilai parameter $\theta$ maka mengakibatkan semakin kecil nilai $R_{0}$ Maka upaya yang dapat dilakukan untuk menekan penyebaran penyakit campak, yaitu dengan meningkatkan proporsi kesembuhan individu terobat.

Dari Gambar 6 dapat dilihat bahwa meningkatnya parameter $\theta$ dan parameter lain tetap, dapat mempengaruhi populasi terinfeksi dan populasi yang melakukan pengobatan. Semakin besar proporsi individu terobat sembuh, maka semakin kecil jumlah populasi infeksi dan populasi yang melakukan pengobatan. Hal ini menunjukkan bahwa proporsi kesembuhan individu terobat cukup berperan dalam menekan penyebaran penyakit campak.

\section{Kesimpulan}

Model penyebaran penyakit campak dengan faktor pengobatan yang disajikan dalam bentuk sistem persamaan diferensial yang melibatkan 6 (enam) variabel, yang selanjutnya disebut model SMEIUR dan memiliki dua titik kesetimbangan, yaitu titik kesetimbangan bebas penyakit dan titik kesetimbangan endemik. Titik kesetimbangan bebas penyakit stabil asimtotik lokal jika $R_{0}<1$ dan titik kesetimbangan endemik stabil asimtotik lokal jika $R_{0}>1$. Berdasarkan simulasi, Pada kondisi $R_{0}<1$, jumlah populasi terinfeksi berkurang hingga habis pada waktu tertentu, sedangkan pada kondisi $R_{0}>1$ jumlah populasi terinfeksi bertambah sehingga terjadi penyebaran penyakit campak. Pada variasi parameter, meningkatkan laju individu terimunisasi menjadi imunisasi lanjut, laju individu terinfeksi yang melakukan pengobatan dan proporsi populasi terobat sembuh dapat mengakibatkan menurunnya $R_{0}$. Hal tersebut menunjukkan bahwa 
meningkatkan laju individu terimunisasi menjadi imunisasi lanjut, laju individu terinfeksi yang melakukan pengobatan dan proporsi populasi terobat sembuh dapat menekan jumlah penderita penyakit campak.

\section{Ucapan Terima Kasih}

Terima kasih kepada Ketua Program Studi Matematika, seluruh dosen pembimbing dan penguji, teman-teman 1NTE6ER dan seluruh pihak yang telah membantu dalam proses penyelesaian artikel ini.

\section{Referensi}

[1] U. Pagalay, Mathematical modeling: Aplikasi pada kedokteran, imunologi, biologi, ekonomi, dan perikanan. Malang: UIN-Maliki Press, 2009.

[2] Kemenkes-RI, Peraturan Menteri Kesehatan Republik Indonesia nomor 12 tahun 2017 tentang penyelenggaraan imunisasi. Jakarta: Kementerian Kesehatan RI, 2017.

[3] — Profil kesehatan Indonesia 2018 [Indonesia Health Profile 2018]. Jakarta: Kementerian Kesehatan RI, 2019.

[4] M. O. Fred, J. K. Sigey, J. A. Okello, J. M. Okwoyo, dan G. J. Kang'ethe, "Mathematical modeling on the control of measles by vaccination: Case study of KISII County, Kenya," The SIJ Transactions on Computer Science Engineering $\mathcal{E}$ its Applications (CSEA), vol. 02, no. 04, hal. 38-46, 2014.

[5] A. Momoh, M. Ibrahim, I. Uwanta, dan S. Manga, "Mathematical model for control of measles epidemiology," International Journal of Pure and Apllied Mathematics, vol. 87, no. 5, 2013.

[6] S. Edward, "A mathematical model for control and elimination of the transmission dynamics of measles," Applied and Computational Mathematics, vol. 4, no. 6, hal. 396, 2015.

[7] S. M. Garba, M. A. Safi, dan S. Usaini, "Mathematical model for assessing the impact of vaccination and treatment on measles transmission dynamics," Mathematical Methods in the Applied Sciences, vol. 40, no. 18, hal. 6371-6388, 2017.

[8] S. Nigusie Mitku, "Mathematical modeling and simulation study for the control and transmission dynamics of measles," American Journal of Applied Mathematics, vol. 5, no. 4, hal. 99, 2017.

[9] E. D. Zanuarini, Jaharuddin, dan E. H. Nugrahani, “Sistem dinamik penyebaran penyakit campak dengan dua tahapan individu terinfeksi," Tesis, Institut Pertanian Bogor, 2018.

[10] S. O. Haryanugroho, "Perilaku Orang Tua Terhadap Penanganan Penyakit Campak pada Anak-Anak," hal. 1-5, 2019.

[11] M. Z. Ndii, Pemodelan matematika. Yogyakarta: Penerbit Deepublish, 2018.

[12] L. Candrawati, "Model matematika SACR penyebaran virus hepatitis C pada pengguna narkoba suntik," Skripsi, Universitas Negeri Yogyakarta, 2014.

[13] P. N. V. Tu, Dynamical systems. Berlin, Heidelberg: Springer Berlin Heidelberg, 1994.

[14] H. W. Hethcote, "The mathematics of infectious diseases," SIAM Review, vol. 42, no. 4, hal. 599-653, 2000.

[15] P. van den Driessche dan J. Watmough, "Reproduction numbers and sub-threshold endemic equilibria for compartmental models of disease transmission," Mathematical Biosciences, vol. 180, no. 1-2, hal. 29-48, 2002. 


\section{Submit your manuscript at http://ejurnal.ung.ac.id/}

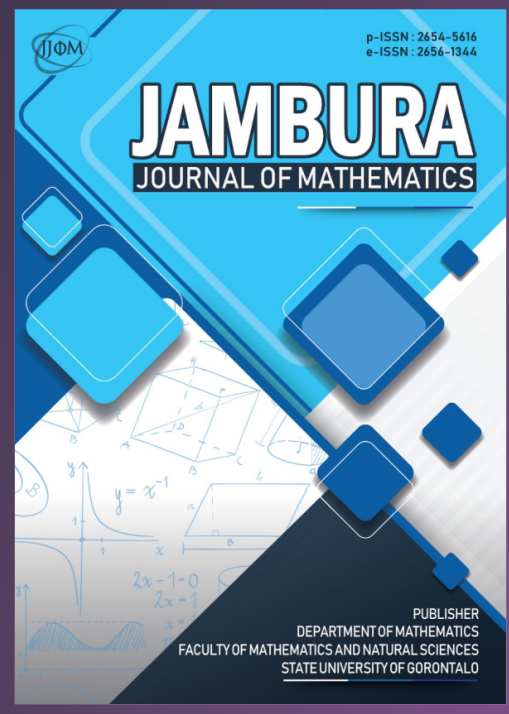

Jambura Journal of Mathematics

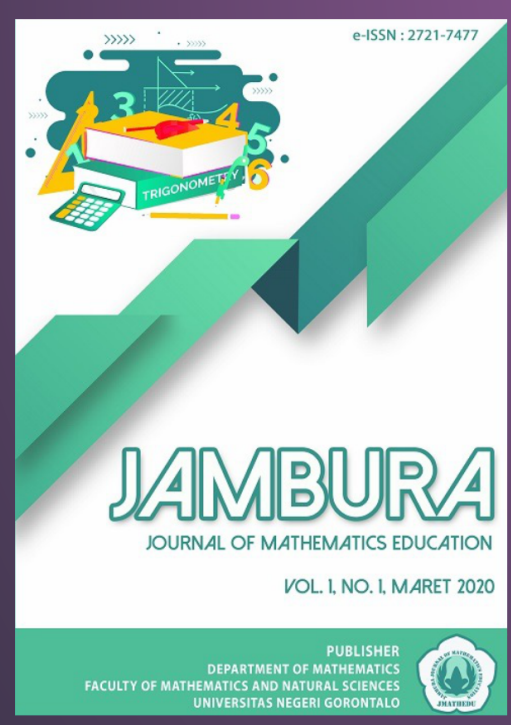

Jambura Journal of Mathematics Education
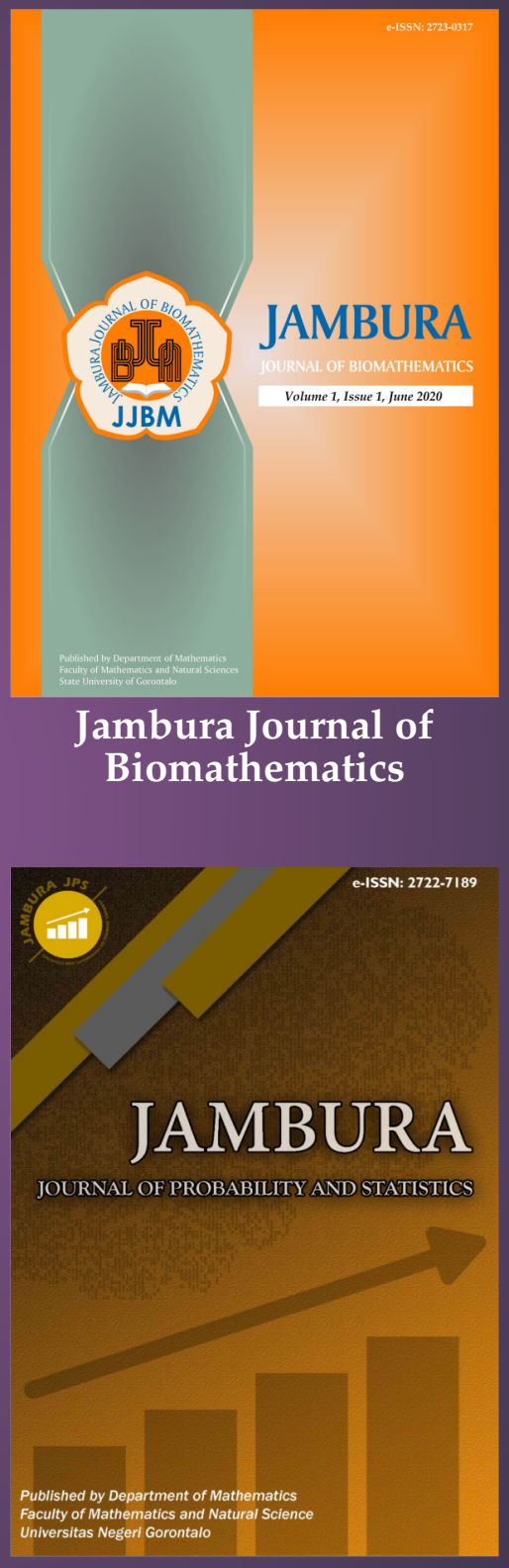

Jambura Journal of Probability and Statistics

Published by

Department of Mathematics

Faculty of Mathematics and Natural Sciences

State University of Gorontalo 